\title{
A STUDY ON MIGRATION OF LABOURS WITH REFERENCE TO TIRUPUR DISTRICT
}

KEY WORDS: Labour Migration, Survival Strategy, Phenomenon

\section{Dr. M.}

Kanagarathinam

Mr. B. Gunasekaran*
Head \& Associate Professor, Department Of Commerce, Nehru Arts And Science College, Coimbatore- 105.

Ph.D Research Scholar, \& And Assistant Professor, Department Of Commerce, Nehru Arts And Science College, Coimabtore-105. *Corresponding Author

Temporary migrants from Uttar Pradesh, Bihar and Jharkhand move out of the state for work. Comparison between temporary and permanent labour migration shows that temporary labour migration is seven times higher than permanent labour migration rate. A regional pattern in temporary labour migration is evident in Tirupur, Coimbatore, Erode District 2018-2019. labour migration is mainly a survival strategy in the country, which is different from the phenomenon of permanent labour migration.

\section{INTRODUCTION}

The huge impact of globalization and concomitant increase in communication and transport facilities in the developing world during the last few decades, the bulk of people migrate within their own country. Global estimates also report that the size of internal migrants is four times larger than that of crossborder migrants (Human Development Report, 2019).. Recent research suggests that internal temporary labour migration plays an important role in household survival in several agrarian economies.

Temporary labour migration plays an important role, not only by securing household survival but also by providing additional income to household members. Yang \& Guo (1999) have found that in rural areas, men's decision to migrate is mainly shaped by community level factors whereas for rural women, temporary labour migration is predominantly determined by individual characteristics. In urban areas, however, individual as well as household factors seem to determine temporary migration (Yang, 2018).

\section{STATEIMENT OF PROBLEM}

Poverty and unemployment are two acute problems common to most of the countries. India is not an exception in this regard. Attainment of higher economic growth is not possible without efforts at employment generation and income augmentation. The population of India is more vulnerable due to socio-economic backwardness. Due to lack of adequate gainful employment opportunities they become excessively dependent on agricultural sectors which add further fuel to the fire.India has a long history of work fare schemes, in which the central and state government works towards livelihood security in rural areas by providing employment.

\section{SCOPE OF STUDY}

The impact of the study is evaluated in terms of employment and income generation, creation of social capitals, assets durability, distressed rural urban migration, savings and investment potentials, expenditure pattern of workers, consumption level, women contribution, household participation, women empowerment, household empowerment, overall performance of the scheme and impact at their village level. Further the study analyses awareness level of workers about the provisions provided under the scheme which make them get employ under the scheme and attain the benefits to empower them econo mically.

\section{OBJECTIVES}

The study is to explore the phenomenon of labour migration in Tirupur and Coimbatore District

1. Examine the socioeconomic conditions of migrated labours.

2. Study the characteristics of migrated labours

3. Study the expectations of migrated labours

4. Study the determinants of Labour Migration

\section{REVIEW OF LITERATURE MIGRATION THEORIES AND TEMPORARY LABOUR MIGRATION}

Several economic theories have been proposed to explain labour migration. For instance, Ravenstein's (1885, 1889) laws of migration, Stouffer's $(1940,1960)$ intervening opportunity model, Lee's theory of migration (1966), and Todaro's analysis of rural-urban migration (Harris \& Todaro, 1970;Todaro, 1969). All of these theories have shown much concern in explaining permanent labour migration with less attention to circular migration (Deshingkar \& Farrington, 2009a).

\section{RAVENSTEIN'S 'LAWS' OF MIGRATION}

During the latter half of 19th century Ravenstein undertook a comprehensive study on migration. In 1885 and later substantiated in 1889, Ravenstein (1885, 1889) made an extensive study on migration in Continental Europe as well as the United States and postulated famous seven "Laws of Migration". A brief description of these seven laws of migration is given below.

\section{LAWS OF MIGRATION:}

1. The great body of our migrants only proceed a short distance, and consequently a universal shifting or displacement of the population takes place, which produces "currents of migration" setting the direction of the great centres of commerce and industry which absorbs the migrants.

2. The process of absorption would go on in the following manner: the inhabitants of the country immediately surrounding a town of rapid growth flock into it; the gaps thus left in the rural population are filled up by migrants from more remote districts, until the attractive force of one of our rapidly growing cities makes its influence felt, step by step to the most remote corner of the kingdom.

3. The process of dispersion is the inverse of that of absorption and exhibit similar features.

4. Each main current of migration produces a compensating counter current.

5. Migrants proceeding long distance generally go by preference to one of the great centres of commerce and industry.

6. The natives of towns are less migratory than those of the rural parts of the country.

7. Females are more migratory than males.Women certainly are greater migrants than men, but they go shorter distances. 
Despite several criticisms, Ravenstein's papers have stood the test of time and remain the starting point for work in migration theory. A reappraisal of the "laws" nearly a century late demonstrated that with few exceptions, Ravenstein's laws adequately describe internal migration in the United States, especially rural-urban migration (Macisco \& Pyror, 1963).

\section{SOURCES OF DATA:}

\section{DATA COLLECTION:}

Data on several aspects of respondents, viz. the migrant labourers will be collected for achieving research objectives. Both qualitative, and quantitative data were collected from two main sources: Primary and Secondary.

The study is based on the socio economic survey in selected areas, where migrant labourers are working in Tirupur and Coimbatore Dt. The study also compares the provisions of labour laws i.e. human rights, minimum wages and workmen compensation acts etc. with actual conditions of the migrant labourers. So, the primary data was collected from the respondents through interview schedules, survey, group discussions and field observations.

\section{RESEARCH PROBLEM:}

This research was been conducted to find out the reasons for rural to urban labour migration. The research, problems, studied were 'why labourers are migrating from village to cities? Is the migration beneficial for them? It is helps to improve their living standard or not? Is the labour migration is major problem before the farmer employers? The research work helped to find the answers of these questions.

\section{LIMITATION OF THE STUDY}

The following are the limitations of the study

1. The research covers Tirupur and Coimbatore District only.

2. Based on their own interest, opinion and distaste the respondents have given the biased opinion.

3. Though there are 109542 registered workers from the sampled panchayats in Virudhunagar District due to research design the researcher has selected 0.5 per cent respondents that constitutes 548 respondents only

\section{PLAN OF ANALYSIS}

The data is analysed by using appropriate statistical tools like Percentage analysis, Chi-square Test, Garrett Ranking Technique, Reliability Test, CramerVTest,

Contingency Co-efficient, Sign Test, One Way ANOVA Test, Confirmatory Factor Analysis and Structural Equation Model with the help of SPSS.

\section{FINDINGS}

1. The major causes of migration of labourers.

2. The changes in living standard of labourers due to migration.

3. The difference between rural and urban employment

4. The changed socio-economic status of the labourers after migration.

6. All conditions of labourers as compared to with human rightsand labour laws.

\section{SUGGESTIONS}

The present research work has focused on the main causes of the labour migration and its consequences also in the form of improvement in the economic conditions of the migrant labourers and the impact on the labourers in the villages.

1. Labourers are migrating because of poverty, unempl oy ment and less income in the rural areas. So, the gover $\mathrm{nm}$ ent should implement the Employment Guarantee Sch emes effectively to give employment and income source to the rural people.

2. It is observed that, illiteracy is also another factor for migration. Illiteracy leads to backwardness. So, labourers and rural people should try to get education. The government should implement the adult education programme rigorously. It could make the next generation literate of such labourers

3. The migrant labourers should try to improve their skills and proficiency to perform various kinds of work, by that they can get employment easily with higher wages.

4. The Government should implement some measures secure the human rights of the migrant labourers. A separate mechanism should be created to safeguard the rights of the migrant labourers.

\section{CONCLUSION}

Most of the male migrant labourers are getting employment in Transportation, Garments,Textiles, Hotel and Shops etc sectors. These were followed by Industries, Brick kilns and construction. As they are less skilled, they go at the works which requires less skills and proficiency, like shops, hotels and transportation etc. It was also observed that, unskilled labourers in transportation sector were working as cleaners or supporting staff. The number of male migrant labourers is very high ascompared to the sum of female migrant labourers. This is because, the males generally have more responsibility to earn the money

\section{REFERENCES}

1. Ishwar C. Dhingra, The Indian Economy Environment and Policy, Sultan Chand and Sons, New Delhi, 2009, p.424

2. Wikipedia.com

3. Vikas B. Postar, "Employment Generated through MGNREGS In Tirupur District of Tamilnadu State", International Referred Research Journal, Vol. III, Issue 27, December 2011,pp.3-5.

4. http:// articles.economictimes.indiatimes.com, October 10,2013.

5. Naomi Jacob, "The Impact of NREGA on Rural Urban Migration Field Survey of Tirupur District, Tamil Nadu", CCS Working Paper No: 22, Summer Research Internship Programme, 2008. 